\title{
Preventing Soil Inoculum of Calonectria pseudonaviculata from Splashing onto Healthy Boxwood Foliage by Mulching
}

T. M. Likins, Chesterfield Cooperative Extension, Chesterfield, VA, USA; P. Kong, Hampton Roads Agricultural Research and Extension Center, Virginia Tech, Virginia Beach, VA, USA; H. F. Avenot, S. C. Marine, and A. Baudoin, School of Plant and Environmental Sciences, Virginia Tech, Blacksburg, VA, USA; and C. X. Hong, ${ }^{\dagger}$ School of Plant and Environmental Sciences, Hampton Roads Agricultural Research and Extension Center, Virginia Tech, Virginia Beach, VA, USA

\begin{abstract}
Boxwood blight, caused by Calonectria pseudonaviculata, is an emerging disease of great concern to horticulturists in the United States and other affected countries. The objective of this study was to evaluate the efficacy of mulching as a physical barrier to prevent soil inoculum from splashing onto healthy boxwood foliage. A field trial consisting of two treatments, mulched and nonmulched, was conducted under field conditions in Lowgap, North Carolina, and in a residential landscape setting near Richmond, Virginia, for 2 years at each site. Mulching efficacy was assessed by monitoring and comparing boxwood blight development on detector plants:

containerized 'Justin Brouwers' boxwood, which were rotated through mulched and nonmulched plots at 1- and 2-week intervals in the Lowgap and Richmond sites, respectively. Boxwood blight was observed on detector plants in a combined 55 of the 88 monitoring periods during this study at the two sites. Mulching provided complete protection of Justin Brouwers boxwood from infection by $C$. pseudonaviculata soil inoculum during 33 of the 55 positive monitoring periods $(60 \%)$ and good to excellent protection during 13 monitoring periods (24\%). The potential applications of mulching for boxwood blight mitigation are discussed.
\end{abstract}

Boxwood (Buxus sempervirens) is an important ornamental crop with an annual wholesale value of over \$126 million in the United States in 2012 (USDA-NASS 2014) and is a mainstay in the landscape, including in many historic gardens (Batdorf 2005). This prominence is attributed to its utility, resiliency, and low maintenance. Boxwood is prized for use as individual specimen plants, hedges, parterres, and landscape groupings. Other important applications include decorative boxwood greeneries for holidays, and boxwood sculptures for learning, ritual purposes, and whimsy. Boxwood plants also are frequently grown as topiary or bonsai due to their high tolerance to heavy pruning.

Once-regarded as a low maintenance plant, boxwood is now threatened by boxwood blight, an emerging disease caused by Calonectria pseudonaviculata. Among the boxwood species, varieties, and cultivars evaluated to date, none is resistant to this disease (Ganci 2014; Gehesquière 2014; LaMondia and Shishkoff 2017; Shishkoff et al. 2015; Van Laere et al. 2015). Boxwood blight has resulted in the loss of over $\$ 5.5$ million worth of boxwood plants in the state of Connecticut alone (LaMondia and Shishkoff 2017). It also has destroyed many historically important and established boxwood gardens, including the garden at the Woodrow Wilson Presidential Museum in Virginia (Moyer 2016).

Current approaches to this disease focus on the use of less susceptible cultivars and frequent fungicide applications (LaMondia 2015).

Current affiliation of S. C. Marine: Department of Biochemistry, Virginia Tech, Blacksburg, VA, USA.

${ }^{\dagger}$ Corresponding author: C. X. Hong; E-mail: chhong2@vt.edu

Funding: This research was supported by the USDA Animal and Plant Health Inspection Service grant numbers 15-8130-0270-CA, 15-8130-0282-CA, 168130-0282-CA, and 17-8130-0282-CA. This project also was supported through the USDA Hatch Fund and the Virginia Agricultural Experiment Station.

*The $\boldsymbol{e}$-Xtra logo stands for "electronic extra" and indicates that one supplementary table is published online.

Accepted for publication 9 August 2018.

(c) 2019 The American Phytopathological Society
Several fungicides, including chlorothalonil, thiophanate-methyl, triazoles, carboxamides, and strobilurins, have consistently provided good protection of boxwood across various study locations (Baudoin et al. 2015; Brand 2006; Gehesquière 2014; Henricot and Wedgwood 2013; Henricot et al. 2008; Ivors et al. 2013; LaMondia 2014). However, the use of these fungicides is limited due to high costs of maintaining effective fungicide programs. Moreover, the use of fungicides for protection of boxwood in historic gardens and homeowner or commercial landscapes is particularly challenging because application visibility, potential pesticide drift, application frequency, and reentry intervals must be considered.

Other major control recommendations are to avoid the purchase and introduction of contaminated plant materials, including pachysandra (Kong et al. 2017b; LaMondia 2017), sweet box (Kong et al. 2017a; Malapi-Wight et al. 2016), and boxwood greeneries (https://vtnews.vt.edu/articles/2016/12/ext-boxwoods.html), as well as to practice stringent sanitation (Dart et al. 2015b; Shishkoff 2016). There also have been several studies exploring biological control of this disease, with Trichoderma koningiopsis (Kong and Hong 2017), RootShield PLUS WP (Yang and Hong 2017), and Pseudomonas protegens (Yang and Hong 2018) being identified as potential biocontrol agents or products.

Safer and more convenient alternatives are needed for the management of boxwood blight. This is particularly true for historic gardens, and home and commercial landscapes, which are most prone to C. pseudonaviculata invasion, while also being the most sensitive to fungicide application and drift. One potential alternative is mulching. Mulching is commonly used in the landscape to suppress weed growth, reduce soil moisture evaporation, maintain soil structure and temperature, and influence soil microorganisms, while being aesthetically pleasing (Batdorf 2005; Kader et al. 2017). Mulching also has been used for disease and pest management (Stirling and Eden 2008), although not commonly with ornamental plants. For boxwood blight, Gehesquière (2014) used mulching as a research tool to assess the relative significance of aerial and direct plant-to-plant watermediated dispersal of $C$. pseudonaviculata spores. Although mulching has not been evaluated for boxwood blight mitigation, it could be an effective management tool for several reasons. First, $C$. pseudonaviculata conidia are sticky; thus their dispersal by air current is minimal (Gehesquière 2014). Second, this pathogen primarily attacks leaves and stems. As the disease progresses, it defoliates the plant. In the worst-case scenario, diseased leaves loaded with the pathogen 
propagules including conidia, microsclerotia, and mycelia will be on the soil surface. Third, there is no evidence to date of natural infection of boxwood roots by $C$. pseudonaviculata, although artificial infection was observed under controlled environments (Dart et al. 2015a; Eskandari and Shishkoff 2017).

These characteristics suggest that boxwood blight may be relatively more manageable than diseases caused by airborne pathogens, and mulching might be an effective control strategy to prevent splashing of soilborne inoculum onto new growth of boxwood. This hypothesis is based on three assumptions. First, all affected foliage is completely removed from the site. Second, all human-based avenues of pathogen dispersal are mitigated, if not completely stopped, by disinfecting all tools, shoes, clothes, and other equipment. Third, access to boxwood plantings to avoid pathogen spread from infected to healthy plants by domestic and wild animals is minimal or restricted. The objective of this study was to test this hypothesis and evaluate the utility of mulching as a strategy for boxwood blight mitigation in two different settings.

\section{Materials and Methods}

This study was conducted under field conditions in Lowgap, NC, and in a residential landscape setting near Richmond, VA.

Trial location and history of boxwood blight: Lowgap site. The Lowgap site was a former commercial boxwood nursery in Surry County (approximately $36^{\circ} 31^{\prime} \mathrm{N}$ and $80^{\circ} 50^{\prime} \mathrm{W}$ ) with loamy soil and surrounded by deciduous forest. Boxwood blight had become established by 2013. Infected boxwood were still present in the field, but no management program was initiated to control the disease. Standard commercial insecticides were applied in spring to control boxwood leaf miner.

At this location, the trial was performed in 34-liter polyethylene plantainers $(66 \mathrm{~cm}$ diameter, $18 \mathrm{~cm}$ height; MacCourt, Denver, CO) filled with all-purpose leveling sand (Quikrete, Atlanta, GA). A 5-liter bucket with two drainage holes was added into the center of each plantainer for placement of the detector plant. Overwintered leaf debris that had accumulated around the base of on-site $B$. sempervirens plants was collected and distributed in a 5-cm layer within each plantainer around each detector plant. C. pseudonaviculata was confirmed in a subsample ( $16 \mathrm{~g})$ of the leaf debris by the presence of sporodochia following incubation in a moist chamber (data not shown). For mulching treatment, leaf debris was covered with a 7-cm layer of cypress mulch (2015) or pine bark mulch (2016). Plantainers were set directly on the grass. In 2015, plantainers were spaced $1 \mathrm{~m}$ apart in a north-south oriented row in a grassy alleyway adjacent to a commercial nursery and were within $2 \mathrm{~m}$ of field-grown symptomatic boxwood. In 2016, plantainers were spaced $3 \mathrm{~m}$ apart in north-south oriented rows in a grassy field more than $45 \mathrm{~m}$ away from the nearest known source of inoculum. Leaf debris was collected immediately prior to the start of the field trial in each year, and fresh wood mulch was purchased from a local supplier in both 2015 and 2016.

Trial location and history of boxwood blight: Richmond site. The Richmond site was a $24,282-\mathrm{m}^{2}$ private property $\left(37^{\circ} 33^{\prime} \mathrm{N}\right.$ and $77^{\circ} 43^{\prime} \mathrm{W}$ ) with over 400 established boxwood. The majority of the plantings were English boxwood (B. sempervirens cv. Suffruticosa) with fewer than three dozen plants of other cultivars including $B$. sempervirens cvs. Elegantissima and Arborescens, and B. microphylla cv. Morris Midget mixed in between. The owner had two dogs that moved freely on the property. Many wild animals also resided on or visited the property on a daily basis because of its proximity to an unmanaged wooded area. Resident animals included squirrels and rabbits, while most common visitors included deer and birds.

Boxwood blight was introduced via contaminated but asymptomatic containerized English boxwood from a retail store in April 2015. The purchased plants were placed by the fence on the east side of the house about $2.5 \mathrm{~m}$ away from the closest established boxwood plantings in the backyard and front yard, respectively. Boxwood blight symptoms were first noticed on established boxwood in midAugust, and the disease was confirmed on 24 August 2015. All boxwood initially displaying symptoms were located in the front yard, except for one that was located in the backyard by an entrance gate. At the same time, the disease symptoms were also observed on the purchased English boxwood, which were contaminated at their originating store and production nursery, as confirmed through trace backs by the Virginia Department of Agricultural and Consumer Services. How $C$. pseudonaviculata spread from newly purchased boxwood to established boxwood plantings several meters away is unknown.

After affected boxwood in the front yard were assessed for disease severity on 6 October 2015, they were grouped by plant size, disease severity, and microclimatic condition. Three most uniform sections of boxwood were selected for this trial. The first section had four large boxwood bushes with two on each side of the steps to the front door. The two boxwood on the east side, hereafter referred to as Block 1, had completely blighted foliage, while those on the west side, hereafter referred to as Block 2, were also severely affected by the disease. The second section had a row of five smaller boxwood under a huge elm tree. These boxwood plants had severe foliage blight with the two on east and west ends designated as Blocks 3 and 4 , respectively. The third section was located in an open area with 23 boxwood of the same size as those in the second section. Two boxwood with completely blighted foliage were selected as Block 5. All selected plants were English boxwood with a substantial amount of fallen leaves on the ground surface. They all were cut in late fall, by early December 2015, to leave stump heights of approximately 15 to $18 \mathrm{~cm}$ in the first section and 13 to $15 \mathrm{~cm}$ in the other sections. All fallen leaves were left on the ground surface, but the pruned material was transported to a dump pile and burned on-site. Plot areas surrounding stumps were $2 \times 2 \mathrm{~m}$.

Trial treatments and experiment design. Two treatments (mulched versus nonmulched control) were evaluated in the study at both sites. At the Lowgap site, each treatment had four replicate plantainers, while at the Richmond site, each treatment had five replicate stump blocks.

At the Lowgap site, treatments were randomized within the rows. Mulch and contaminated leaf debris were periodically replenished throughout the monitoring period to maintain the desired depth. Grasses between plantainers were mowed occasionally in 2015 and three times between June and September in 2016.

At the Richmond site, treatments were arranged in a randomized complete block design. The area of mulched plots was overlaid with an 8- to 10-cm layer of pine bark purchased from Yard Works, Powhatan, VA. The thickness of the mulch layer was based on the competing goals of preventing $C$. pseudonaviculata from the soil surface splashing onto regrowth of boxwood stumps or detector plants, while simultaneously allowing for adequate water drainage for a shallowly rooted plant like boxwood. A $61 \times 91 \mathrm{~cm}$ Plexiglas sheet attached to a stake was installed vertically between two treatment plots in Blocks 3 to 5 to reduce the potential of $C$. pseudonaviculata cross contamination from nonmulched to mulched plots by rain splash. Additional pine bark was added to mulched plots to maintain the thickness, as designated before the growing season began in 2017 .

Monitoring $C$. pseudonaviculata dispersal from soil surface to boxwood foliage. Containerized $C$. pseudonaviculata-free $B$. sempervirens Justin Brouwers boxwood were used as detector plants at both sites to monitor water splash dispersal of $C$. pseudonaviculata from the soil surface to healthy plant foliage. All detector plants were provided by Saunders Brothers, Inc. (Piney River, VA).

For the Lowgap field trial, detector plants were grown in 3.8-liter pots with potting mix (56\% composted pine bark, $32 \%$ coarse Perlite, and $12 \%$ peat moss). Plants were kept in a greenhouse on Virginia Tech's Blacksburg campus up to 2 years prior to placement in the research plots. Plants were watered with tap water daily and fertilized with Osmocote Plus 15-9-12 (Everris NA Inc., Dublin, OH) as needed.

Upon arrival at the Lowgap site, one detector plant was installed per plantainer. Each plant was placed into a 5-liter plastic bucket with two holes drilled in the sides. Holes were positioned so that approximately $3 \mathrm{~cm}$ of standing water could accumulate in the bucket, which helped maintain soil moisture and minimize drought stress 
between site visits. Detector plants were replaced with healthy boxwood on a weekly basis starting in mid-May of 2015 and 2016 (Table 1). Upon return to the lab, detector plants were placed in an incubator (model SRI21D; Sheldon Manufacturing Inc., Cornelius, OR), and blighted leaves and lesions per plant were counted the following day. Detector plants were then incubated for $\sim 7$ days under day/night temperatures of $25 / 20^{\circ} \mathrm{C}$ with a 14 -h photoperiod, at which time all symptomatic leaves were removed, and the total number of blighted leaves and lesions per plant was determined. Subsequently, disease severity was assessed for each detector plant on a 0 to 10 scale based on the percentage of leaves blighted: 0 for no disease, and rating increasing 1 with an increase of diseased leaves by 1 to $10 \%$. For example, a plant with 1 to $10 \%$ leaves blighted was rated as 1 , while that with 91 to $100 \%$ leaves blighted was rated as 10 . In both 2015 and 2016, to confirm the presence of $C$. pseudonaviculata, a subset of blighted leaves was placed in a petri dish containing moistened filter paper (Sigma-Aldrich, St. Louis, MO) and kept in a plastic bag misted with sterile water at room temperature. After 4 days, the leaves were examined under a dissecting microscope (model SZ-PT; Olympus Corporation, Tokyo, Japan) with fiber optic light source (model 8375; Schott-Fostec, Auburn, NY) for the presence of sporodochia bearing conidia. Development of boxwood blight was monitored for a total of 26 weeks in 2015 (from 19 May until 17 November) and 30 weeks in 2016 (from 18 May until 14 December).

For the Richmond residential trial, detector boxwood plants were grown in new Azalea plastic containers (15 cm in diameter) with Metro Mix 830 (Sun Gro Horticulture, Agawam, MA, USA) and pine bark in a 1:1 ratio in early spring on a gravel pad at the Virginia Tech's Hampton Roads Agricultural Research and Extension Center in Virginia Beach until use. Plants were fertilized with Osmocote 179-11 and irrigated one to three times a day, depending upon the time of year, prior to placement in the research plots.
At this site, monitoring of $C$. pseudonaviculata dispersal and infection in the research plots began on 20 April 2016 and continued through 9 November (Table 2). One detector plant was placed within the dripline of each replicate plot for 3 weeks during the first monitoring period. At the end of 3 weeks, the plants were removed from the plots and a new set of plants was installed. Thereafter, detector plant rotation was repeated at 2-week intervals throughout the growing season. The total number of monitoring periods was 14 . Aluminum pie pans were placed under the plant containers to minimize water stress.

The plants rotated out of Richmond research plots were visually scored for boxwood blight using the same rating scale of 0 to 10 as used for the Lowgap trial. Detector plants were then moved to a wire-fenced corner on the same property to allow disease symptom expression for two more weeks while minimizing contact with animals. At the end of the second week, plants were visually scored again for boxwood blight. When disease symptoms were atypical of boxwood blight, symptomatic leaves or stems were taken to the lab for microscopic examination and for further incubation in a moist environment when needed. Upon completion of the disease assessment, all plants were bagged and disposed of at a local sanitary landfill.

The residential planting study was repeated in 2017, starting on 21 April and continuing through 29 November (Table 2). The number of detector plants was increased to 3 per replicate plot for a total of 30 per monitoring period. Detector plants were replaced with a new set of plants at 2-week intervals without exception. As a result, the total number of monitoring periods was 16 in 2017.

Weather monitoring. As boxwood blight development is known to be weather-dependent (Avenot et al. 2017; Gehesquière 2014), weather data at both the Lowgap and Richmond sites were recorded every 15 min using Em50G data loggers (Decagon Devices Inc., Pullman, WA) with the following probes: anemometer (model Davis

Table 1. Start and end dates of each monitoring period at the Lowgap field site in 2015 and 2016, and presence (+) or absence (-) of boxwood blight on detector plants after an additional week of incubation in a growth chamber at $25^{\circ} \mathrm{C}$ day $/ 20^{\circ} \mathrm{C}$ night

\begin{tabular}{|c|c|c|c|c|c|c|}
\hline \multirow[b]{2}{*}{ Monitoring period } & \multicolumn{3}{|c|}{2015} & \multicolumn{3}{|c|}{2016} \\
\hline & Start & End & Boxwood blight & Start & End & Boxwood blight \\
\hline 1 & 19 May & 26 May & + & 18 May & 25 May & - \\
\hline 2 & 26 May & 2 June & + & 25 May & 1 Jun & + \\
\hline 3 & 2 June & 9 June & + & 1 Jun & 8 Jun & + \\
\hline 4 & 9 June & 16 June & + & 8 Jun & 15 Jun & - \\
\hline 5 & 16 June & 23 June & + & 15 Jun & 22 Jun & - \\
\hline 6 & 23 June & 30 June & + & 22 Jun & 29 Jun & + \\
\hline 7 & 30 June & 7 July & + & 29 Jun & $6 \mathrm{Jul}$ & + \\
\hline 8 & 7 July & 14 July & - & $6 \mathrm{Jul}$ & $13 \mathrm{Jul}$ & + \\
\hline 9 & 14 July & 21 July & - & $13 \mathrm{Jul}$ & $21 \mathrm{Jul}$ & + \\
\hline 10 & 21 July & 28 July & - & $21 \mathrm{Jul}$ & $28 \mathrm{Jul}$ & - \\
\hline 11 & 28 July & 4 Aug & - & $28 \mathrm{Jul}$ & 4 Aug & + \\
\hline 12 & 4 Aug & 11 Aug & - & 4 Aug & $11 \mathrm{Aug}$ & + \\
\hline 13 & 11 Aug & 17 Aug & + & 11 Aug & 16 Aug & - \\
\hline 14 & 17 Aug & 25 Aug & + & 16 Aug & 24 Aug & + \\
\hline 15 & 25 Aug & 1 Sep & + & 24 Aug & 31 Aug & + \\
\hline 16 & 1 Sep & 8 Sep & + & 31 Aug & 7 Sep & + \\
\hline 17 & 8 Sep & $15 \mathrm{Sep}$ & + & 7 Sep & 14 Sep & - \\
\hline 18 & 15 Sep & $23 \mathrm{Sep}$ & + & 14 Sep & 21 Sep & + \\
\hline 19 & $23 \mathrm{Sep}$ & $30 \mathrm{Sep}$ & + & $21 \mathrm{Sep}$ & $28 \mathrm{Sep}$ & + \\
\hline 20 & 30 Sep & 7 Oct & + & 28 Sep & 5 Oct & + \\
\hline 21 & 7 Oct & 14 Oct & + & 5 Oct & 12 Oct & + \\
\hline 22 & $14 \mathrm{Oct}$ & $21 \mathrm{Oct}$ & + & $12 \mathrm{Oct}$ & 19 Oct & - \\
\hline 23 & $21 \mathrm{Oct}$ & 29 Oct & + & 19 Oct & 26 Oct & + \\
\hline 24 & 29 Oct & 4 Nov & + & 26 Oct & $2 \mathrm{Nov}$ & - \\
\hline 25 & $4 \mathrm{Nov}$ & $11 \mathrm{Nov}$ & + & $2 \mathrm{Nov}$ & $9 \mathrm{Nov}$ & + \\
\hline 26 & $11 \mathrm{Nov}$ & $17 \mathrm{Nov}$ & + & $9 \mathrm{Nov}$ & $17 \mathrm{Nov}$ & + \\
\hline 27 & & & & $17 \mathrm{Nov}$ & $23 \mathrm{Nov}$ & - \\
\hline 28 & & & & $23 \mathrm{Nov}$ & $1 \mathrm{Dec}$ & + \\
\hline 29 & & & & $1 \mathrm{Dec}$ & 7 Dec & + \\
\hline 30 & & & & $7 \mathrm{Dec}$ & $14 \mathrm{Dec}$ & - \\
\hline Positives/Total & & & $21 / 26$ & & & $20 / 30$ \\
\hline
\end{tabular}


Cup), pyranometer (model PYR), rain gauge (model ECRN-100), leaf wetness sensor (model LWS), and temperature sensor (model ECT). Parameters recorded were photosynthetically active radiation $\left(\mu \mathrm{mol} / \mathrm{m}^{2} \mathrm{~s}\right)$, precipitation $(\mathrm{mm})$, relative humidity $(\%)$, temperature $\left({ }^{\circ} \mathrm{C}\right)$, wind direction and speed, and leaf wetness duration (h). Recorded data were downloaded with $\mathrm{ECH}_{2} \mathrm{O}$ software from the data logger to a laptop at every site visit.

Data were summarized to determine the daily minimum, average, and maximum for all parameters as well as the sum for precipitation and leaf wetness. Data collected at the Lowgap site between 19 May and 17 November were further summarized to determine the average temperature and relative humidity, cumulative rainfall, and leaf wetness duration for the purpose of comparison between years. Likewise, data collected at the Richmond site between 29 April and 7 November were summarized for the same purposes.

Statistical analysis. Disease severity ratings were converted to the midpoint of each class prior to parametric statistical analysis. Since detector plants were replaced with a new set of detector plants at 1-week (Lowgap) or 2-week intervals (Richmond), disease development on detector plants in one monitoring period did not affect the results of the next monitoring periods. Accordingly, a simple twoway analysis of variance was performed to determine the significance of difference in disease severity between the treatments and among the blocks using the ANOVA Procedure of Statistical Analysis Software Version 9.4 (SAS Institute, Cary, NC), followed by a $t$ test for separation by individual monitoring period. An additional analysis focusing on blight-positive monitoring periods was done using the Sign test to determine the significance of difference in disease severity rating between the two treatments for each research site and year.

\section{Results}

Boxwood blight development on detector plants. Boxwood blight was observed on detector plants in most monitoring periods of both 2015 and 2016 at the Lowgap site. Boxwood blight was observed on detector plants in 21 of the 26 (or $81 \%$ ) monitoring periods in 2015, and 20 of the 30 monitoring periods (or 67\%) in 2016 (Table 1). Although some detector plants had a substantial number of boxwood blight lesions, none had more than $10 \%$ leaves blighted, and disease severity was low for the majority of the periods in which disease was observed. There were more than 10 lesions per four plants in only 8 periods in 2015 and in 3 periods in 2016 (Supplementary Table S1). More than 100 lesions per four detector plants were observed only in four periods in 2015 and none in 2016.

More boxwood blight was observed on detector plants at the Richmond site in 2016 than in 2017. The percentage of monitoring periods positive for boxwood blight was 79\% (or 11/14) in 2016, but only 19\% (or 3/16) in 2017 (Table 2). The only three negative monitoring periods in 2016 were \#8 (3 to 17 August), \#9 (17 to 31 August), and \#14 (26 October to 9 November). In contrast, only 3 of the 16 monitoring periods in 2017 were positive for the disease (Table 2); they were: \#3 (17 to 31 May), \#12 (20 September to 4 October), and \#13 (4 to 18 October). Boxwood blight severity was also much greater in 2016 than in 2017 , with the greatest average severity reading of 8.2 for 2016 , compared with the greatest average severity reading of 0.1 for 2017 .

As expected, more severe boxwood blight developed on detector plants in the more shaded blocks (i.e., Blocks 3 and 4) than in the other blocks. This difference was significant in three monitoring periods of 2016: \#3 from 25 May to 8 June $(P=0.0280)$, \#5 from 22 June to 6 July $(P=0.0018)$, and \#11 from 14 to 28 September $(P=0.0444)$. A similar trend in some other monitoring periods was also observed, although those differences were not statistically significant (data not shown).

Weather conditions and impacts on boxwood blight development. Among all of the weather parameters monitored, the most significant distinctions between 2 years at the Richmond site were rainfall and leaf wetness duration (Table 3). It was much wetter and slightly warmer in 2016 than in 2017 (Table 3). Specifically, the total rainfall during this period in 2016 was much more than that of 2017 (706.2 versus $372.4 \mathrm{~mm}$ ). Similarly, total leaf wetness was $1,250.1 \mathrm{~h}$ for 2016 while only $824.3 \mathrm{~h}$ for 2017 during the same period. In addition, rainfall and hours of leaf wetness were more evenly distributed throughout the year of 2016 than 2017 (data not shown). As expected, more boxwood blight was associated with a larger quantity and more evenly distributed rainfall and leaf wetness in 2016. Likewise, no disease developed during August and November of both years because of unfavorably high or low temperature (data not shown). Comparatively, the cumulative rainfall at the Lowgap site between 2015 and 2016 was close (599.6 versus $550.0 \mathrm{~mm}$ )

Table 3. Summary of weather conditions at the Richmond residential site from 29 April to 7 November over 2 years

\begin{tabular}{lrr}
\hline Parameter & $\mathbf{2 0 1 6}$ & $\mathbf{2 0 1 7}$ \\
\hline Average minimum temperature $\left({ }^{\circ} \mathrm{C}\right)$ & 16.0 & 15.3 \\
Average temperature $\left({ }^{\circ} \mathrm{C}\right)$ & 21.3 & 20.9 \\
Average maximum temperature $\left({ }^{\circ} \mathrm{C}\right)$ & 28.5 & 28.7 \\
Cumulative rainfall $(\mathrm{mm})$ & 706.2 & 372.4 \\
Cumulative leaf wetness duration $(\mathrm{h})$ & $1,250.1$ & 824.3 \\
Average minimum relative humidity $(\%)$ & 60.8 & 58.8 \\
Average relative humidity $(\%)$ & 84.9 & 84.1 \\
Average maximum relative humidity $(\%)$ & 98.5 & 98.2 \\
\hline
\end{tabular}

Table 2. Start and end dates of each monitoring period at the Richmond residential site in 2016 and 2017, and presence (+) or absence (-) of boxwood blight on detector boxwood plants after an additional 2-week incubation in an on-site fenced area

\begin{tabular}{|c|c|c|c|c|c|c|}
\hline \multirow[b]{2}{*}{ Monitoring period } & \multicolumn{3}{|c|}{2016} & \multicolumn{3}{|c|}{2017} \\
\hline & Start & End & Boxwood blight & Start & End & Boxwood blight \\
\hline 1 & $20 \mathrm{Apr}$ & 11 May & + & $21 \mathrm{Apr}$ & 3 May & - \\
\hline 2 & 11 May & 25 May & + & 3 May & 17 May & - \\
\hline 3 & 25 May & 8 Jun & + & 17 May & 31 May & + \\
\hline 4 & 8 Jun & 22 Jun & + & 31 May & 14 Jun & - \\
\hline 5 & 22 June & $6 \mathrm{Jul}$ & + & 14 Jun & 28 Jun & - \\
\hline 6 & $6 \mathrm{Jul}$ & $20 \mathrm{Jul}$ & + & 28 Jun & $12 \mathrm{Jul}$ & - \\
\hline 7 & $20 \mathrm{Jul}$ & $3 \mathrm{Aug}$ & + & $12 \mathrm{Jul}$ & $26 \mathrm{Jul}$ & - \\
\hline 8 & 3 Aug & 17 Aug & - & $26 \mathrm{Jul}$ & 9 Aug & - \\
\hline 9 & 17 Aug & 31 Aug & - & 9 Aug & 23 Aug & - \\
\hline 10 & 31 Aug & 14 Sep & + & 23 Aug & 6 Sep & - \\
\hline 11 & 14 Sep & 28 Sep & + & 6 Sep & 20 Sep & - \\
\hline 12 & $28 \mathrm{Sep}$ & $12 \mathrm{Oct}$ & + & $20 \mathrm{Sep}$ & 4 Oct & + \\
\hline 13 & 12 Oct & 26 Oct & + & 4 Oct & 18 Oct & + \\
\hline 14 & 26 Oct & $9 \mathrm{Nov}$ & - & 18 Oct & $1 \mathrm{Nov}$ & - \\
\hline 15 & & & & $1 \mathrm{Nov}$ & $15 \mathrm{Nov}$ & - \\
\hline 16 & & & & $15 \mathrm{Nov}$ & $29 \mathrm{Nov}$ & - \\
\hline Positives/Total & & & $11 / 14$ & & & $3 / 16$ \\
\hline
\end{tabular}


(Table 4). Likewise, the cumulative leaf wetness was similar, at 1,555.9 and 2,222.4 h for 2015 and 2016, respectively.

Effect of mulching on boxwood blight development. Significantly more boxwood blight was observed on detector plants from nonmulched plots than mulched plots in all positive monitoring periods at both Lowgap and Richmond sites, with a few exceptions (Table 5). At the Richmond site, boxwood blight was only observed on detector plants from the nonmulched control plots, but not on those from mulched plots during 5 of the 11 blight-positive monitoring periods (\#1, \#4, \#6, \#10, and \#13) in 2016 (Fig. 1) and during all 3 positive periods in 2017 (data not shown). Similarly, significantly $(P<0.0278)$ more severe boxwood blight was observed on detector plants from nonmulched plots than those from the mulched plots during six blight-positive monitoring periods (\#3 to \#6, \#11 to \#12) in 2016 (Fig. 1). Numerical differences of the same trend were also observed between the two treatments during the four other blightpositive monitoring periods (Fig. 1), although they were not statistically significant. The monitoring period \#7 of 2016 (20 July to $3 \mathrm{Au}-$ gust) was the only exception during this 2-year trial at the Richmond site where boxwood blight was seen on detector plants from mulched plots but not on those from nonmulched plots. At the Lowgap site, boxwood blight was only seen on detector plants from nonmulched plots and not from any mulched plots during 9 of the 21 blightpositive monitoring periods (\#3, \#6, \#13, \#15, \#18, \#21-22, $\# 25-26$ ) in 2015 , and during 17 of the 20 positive monitoring periods (\#1, \#6-7, \#9, \#11-12, \#14-16, \#18-20, \#23, \#25-26, \#28-29) in 2016. There was one exception in 2015 (\#14), during which the disease was observed on detector plants from mulched plots but not from nonmulched plots.

According to the Sign test, significantly more boxwood blight developed on detector plants in the nonmulched than mulched plots at the Lowgap site in both 2015 and 2016 and at the Richmond site in 2016 (Table 5). The Sign test was not performed for the Richmond site in 2017 due to the small number of blight-positive monitoring periods. At Lowgap, the number of lesions in the mulched treatment was reduced by approximately $96 \%$ in both seasons: 66 (mulched) versus 1,739 lesions in 2015, and 21 versus 504 lesions in 2016. In weeks in which the leaf debris treatment sustained more than 100 lesions per four plants, mulch reduced the lesion number by 97.5 and $100 \%$ in 2015 and 2016, respectively, whereas the reduction was

Table 4. Summary of weather conditions at the Lowgap field site from 19 May to 17 November over 2 years

\begin{tabular}{lrr}
\hline Parameter & $\mathbf{2 0 1 5}$ & $\mathbf{2 0 1 6}$ \\
\hline Average daily minimum temperature $\left({ }^{\circ} \mathrm{C}\right)$ & 13.9 & 13.6 \\
Average temperature $\left({ }^{\circ} \mathrm{C}\right)$ & 19.4 & 20.0 \\
Average daily maximum temperature $\left({ }^{\circ} \mathrm{C}\right)$ & 26.2 & 27.8 \\
Cumulative rainfall $(\mathrm{mm})$ & 599.6 & 550.0 \\
Cumulative leaf wetness duration $(\mathrm{h})$ & $1,555.9$ & $2,222.4$ \\
Average daily minimum relative humidity $(\%)$ & 57.2 & 530.9 \\
Average relative humidity $(\%)$ & 81.0 & 79.8 \\
Average daily maximum relative humidity $(\%)$ & 96.8 & 96.3 \\
\hline
\end{tabular}

$63.8 \%$ in 2015 and $82.6 \%$ in 2016 for weeks in which the leaf debris treatment sustained fewer than 10 lesions per four plants.

Overall, mulching provided excellent protection of Justin Brouwers boxwood from infection by soil inoculum of $C$. pseudonaviculata in 76 and $90 \%$ of the positive monitoring periods under field conditions at the Lowgap site in 2015 and 2016, respectively (Fig. 2). In the residential landscape setting at Richmond site, mulching provided complete protection of Justin Brouwers during all three positive monitoring periods in 2017 , and excellent protection for $82 \%$ of the positive monitoring periods in 2016 (Fig. 2).

\section{Discussion}

Boxwood blight is an emerging disease of great concern to horticulturists, including growers, retailers, landscapers and ground maintenance personnel, public garden managers, and homeowners. This study demonstrated that mulching is an effective tool for boxwood blight mitigation in infested landscape settings, providing complete protection of detector plants during 33 of the 55 positive monitoring periods at two research sites for 2 years $(60 \%)$. These results have several potential implications for disease mitigation while adding value to mulching practice, a landscape management technique commonly used in the United States (Batdorf 2005).

This study adds a new technique to the toolbox for mitigating boxwood blight in landscapes where it matters the most now. Three major efforts have been undertaken nationally or at the state level to mitigate the movement of contaminated plant materials. First, the National Plant Board (http://nationalplantboard.org/) developed and continually promotes the Boxwood Blight Cleanliness Program to guide boxwood growers to produce clean and healthy crops, while advising boxwood buyers to purchase plants only from those participating in the Cleanliness Program. Second, the Virginia Department of Agricultural and Consumer Services routinely inspects incoming boxwood and other host plant materials for boxwood blight and imposes regulatory protocols on contaminated materials. Third, the State of Pennsylvania enacted a full quarantine action against $C$. pseudonaviculata and boxwood blight on 25 June 2016, with the State of Tennessee instituting a similar action on 4 February 2018. Likewise, the State of Illinois declared boxwood blight a nuisance on 4 April 2017, which enabled the State Department of Agriculture to take appropriate steps to eradicate any plants that have or may be showing symptoms of the disease. While these efforts have slowed the spread of this destructive disease, contaminated plant materials have been intercepted in an increasing number of states in the United States with a majority of the positive detections originating from landscapes. Thus, the landscape is currently a hot spot in boxwood blight spread and management. Addition of this mulching technique to the toolbox is timely and should help mitigate the negative impacts of accidental C. pseudonaviculata introductions by reducing plant losses and lessening fungicide treatment cost at the points of contamination, and more importantly, decreasing the risk of this disease radiating outward to adjacent boxwood plantings and production nurseries. Mulching has the potential for boxwood blight mitigation at production facilities as well; however, such applications are

Table 5. Summary of boxwood blight-positive monitoring periods by comparative severity ratings between nonmulched (Non) and mulched (Mulch) plots at each research site and year

\begin{tabular}{|c|c|c|c|c|c|c|}
\hline \multirow[b]{2}{*}{ Site } & \multirow[b]{2}{*}{ Year } & \multirow[b]{2}{*}{ Total positive periods ${ }^{a}$} & \multicolumn{3}{|c|}{ Number of positive monitoring periods } & \multirow[b]{2}{*}{$\boldsymbol{P}$} \\
\hline & & & Non $>$ Mulch $^{\mathbf{b}}$ & Mulch $>$ Non & Non=Mulch & \\
\hline \multirow[t]{2}{*}{ Lowgap } & 2015 & 21 & $17(9)$ & 2 & 2 & $<0.05$ \\
\hline & 2016 & 20 & $18(16)$ & 1 & 1 & $<0.05$ \\
\hline \multirow[t]{2}{*}{ Richmond } & 2016 & 11 & $10(5)$ & 1 & 0 & $<0.05$ \\
\hline & 2017 & 3 & $3(3)$ & 0 & 0 & $-\mathrm{c}$ \\
\hline$\Sigma$ & & 55 & $48(33)$ & 5 & 2 & \\
\hline
\end{tabular}

a Total number of monitoring periods during which boxwood blight was observed on detector plants.

${ }^{\mathrm{b}}$ Listed in parentheses are numbers of positive monitoring periods, during which boxwood blight was only observed on detector plants from nonmulched but not from mulched plots.

${ }^{\mathrm{c}}$ Not calculated due to limited number of positive monitoring periods. 
discouraged at this time, especially for production nurseries participating in the Boxwood Blight Cleanliness Program.

This study may also help sustain boxwood production in the United States and other affected countries by better protecting and expanding the existing boxwood plantings. Landscapes including private and public gardens/spaces remain one of the weakest links in the boxwood blight management programs in the United States. As accidental introductions via contaminated plant and planting materials continue to emerge, they often have an immediate impact in terms of devastating plants and financial losses. The worst-case scenario often occurs where accidental introduction of boxwood blight results in loss of hundreds of historic and established boxwood plantings that have been family and/or public treasures for generations, like the private Richmond property where this study was conducted and the Woodrow Wilson Presidential Museum in Virginia (Moyer 2016). These experiences can erode both private and public gardeners' passion for boxwood and threaten the viability of the boxwood nursery industry. Ideally, with this mulching technique, owners and managers of established gardens, public and private alike, will be able to grow healthy boxwood from regrowth, after completely removing the previously $C$. pseudonaviculata-affected foliage and mulching the ground surface to cover all fallen leaves left behind. It will take some years to rebuild the boxwood gardens, but providing private and public gardeners with additional effective nonfungicidal management tools is a step in the right direction.

The finding that mulching treatment provided complete protection of detector plants during most $(60 \%)$, but not all, blight-positive monitoring periods during this study highlights the importance of using this new technique in an integrated approach, instead of using it alone for boxwood blight mitigation. Three factors at the Richmond site could have contributed to why mulching significantly reduced, but not completely prevented, boxwood blight development during the course of this study. First, the property owner elected not to remove all affected boxwood from the front yard when the trial was initiated, and the disease continued to spread to then healthy plants throughout the 2-year period. Those old and newly diseased boxwood left on the property may have served as additional sources of inoculum. Second, although pine bark mulch covered the selected stump areas, mulch was not added outside of the trial areas, so frequently traversed walkways and steps may have been in contact with infected plant materials or contaminated planting materials, tools, equipment, and personal belongings. Those nonmulched areas other than the control plots could have been another source of inoculum for the detector plants during this trial. Third, domestic and wild animals were not restricted from access to the boxwood planting areas including field plots; they more than likely could have spread C. pseudonaviculata from the two alternative inoculum sources described above to the detector plants on mulched plots in 2016. Likewise, they could have spread the pathogen from the purchased boxwood to the established plantings in the first place. Several measures were considered to restrict animal access to the research plots, but none was implemented due to impracticality and questionable benefit under the circumstances at the site of study. Managing domestic animals, such as cats and dogs, was doable, but such effort does not make sense in isolation, as the relative contribution of domestic animals versus wild

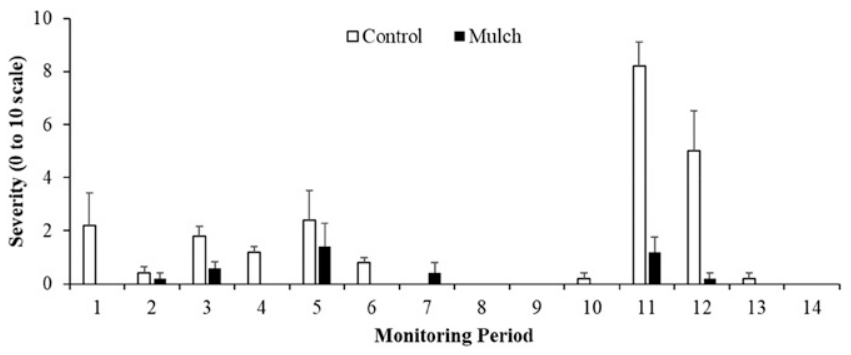

Fig. 1. Ratings of boxwood blight severity on detector plants - 'Justin Brouwers' boxwood 2 weeks after they were removed from mulched and nonmulched plots at the Richmond research site in 2016. animals to the spread of boxwood blight is unknown. Fencing the research plots or caging the areas including the detector plants were considered as means to restrict wild animal access, but both were rejected by the property owner for aesthetic reasons. In addition, fencing would not have stopped birds and insects from accessing the detector plants and potentially introducing C. pseudonaviculata. In addition to bringing in inoculum from elsewhere, animals may disturb the mulch layer by digging in it and bringing inoculum to the surface. Similar problems were encountered at the Lowgap site during this study. These three factors encountered in the present study are realities faced by many, if not all, other landscapes. Thus, an integrated approach is key to maximize the performance and benefits of mulching treatment for boxwood blight mitigation.

There are also some technical aspects that warrant further investigation for enhanced utility and performance of the mulching technique. First, the utility of this technique increases with the regrowth of heavily pruned boxwood. Among the 31 boxwood of different ages and sizes present in locations where this study was performed, only three had regrowth in 2016. To address this limited regrowth issue, we did a preliminary study in 2017, where affected English boxwood were pruned to different heights (15, 25, 41, and $46 \mathrm{~cm}$ ). All stumps taller than $15 \mathrm{~cm}$ had regrowth. Thus, stump height was a major reason for limited regrowth of boxwood during this study at the Richmond site. What the lowest stump height required for regrowth is, and whether this minimum height depends upon boxwood age and size, are both important questions yet to be answered. The best time for pruning boxwood is typically later February and early March in central Virginia (Batdorf 2005), where the Richmond site was located, while boxwood used in that site were pruned in late fall (i.e., early December 2015). Thus, pruning time could have been a critical factor. Another factor of potential significance is the thickness of the mulch layer. Thinner layers of mulch, which aid in water infiltration, are often recommended for shallowrooted plants like boxwood, but may be inadequate for disease management. Second, pine bark mulch degrades quickly, requiring the addition of new mulch every year to ensure the contaminated soil surface remains covered. This could be a burdensome practice, especially with pathogens like $C$. pseudonaviculata that may have long survival of microsclerotia in soil (Ganci 2014; Henricot et al. 2008). Additional studies are warranted to investigate alternative mulches, including living mulches or cover crops, as control options. Groundcover crops that could grow quickly and thrive under boxwood, while not serving as a host for C. pseudonaviculata, are also a worthwhile area for further exploration. Third, as discussed above, mulching efficacy depends largely on whether other sources of inoculum and other avenues of pathogen dispersal are present and to what degree these vulnerabilities are being addressed. Thus,

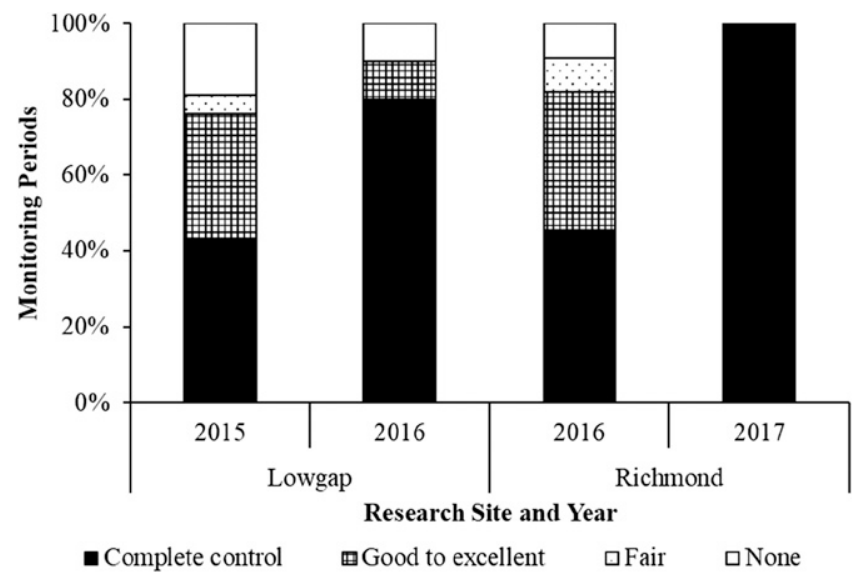

Fig. 2. Mulching efficacy for control of boxwood blight as measured by the distribution of positive monitoring periods among four categories: Complete control (100\%), Good to excellent (50 to $99 \%$ control), Fair ( $<50 \%$ control), and No control $(0 \%$ control) at each research site in each year. 
another important question is how to best integrate this new technique into a comprehensive management plan with other mitigation tools. Additional studies are warranted to examine the potential synergisms among them, so site-specific integrated disease management programs can be developed and implemented for the best performance.

This study also highlights the importance of local weather conditions, especially rainfall, leaf wetness duration, and temperature in boxwood blight epidemics and their contribution to disease pressure build-up (Avenot et al. 2017; Gehesquière 2014). The effects of these and other weather parameters on disease onset and progression at both research sites and years are still being analyzed. These analyses are of importance to delineate the field epidemiology of boxwood blight. They also have the potential to further refine an online boxwood blight disease forecasting model (http://uspest.org/risk/ models?mdl=bxwd_s) and may aid in the development of sitespecific boxwood blight management. These analyses will be reported separately for adequate coverage.

\section{Acknowledgments}

The authors are grateful to the property owners of the Richmond, Virginia, and Lowgap, North Carolina, sites for providing access and on-site assistance, and to Saunders Brothers, Inc. for providing the liners of all detector plants used in this study. Our thanks extend to P. Richardson, T. Wilchynski, and A. Mashaheet for assistance in setting up the weather stations or potting and managing detector plants.

\section{Literature Cited}

Avenot, H. F., King, C., Edwards, T., Baudoin, A., and Hong, C. X. 2017. Effects of inoculum dose, temperature, cultivar, and interrupted leaf wetness period on infection of boxwood by Calonectria pseudonaviculata. Plant Dis. 101: 866-873.

Batdorf, L. R. 2005. Boxwood Handbook - A Practical Guide to Knowing and Growing Boxwood. The American Boxwood Society, Boyce, VA.

Baudoin, A., Avenot, H. F., Edwards, T., Diallo, Y., and Lucernoni, C. 2015. Evaluation of fungicides for control of boxwood blight, 2014. Plant Dis. Manage. Rep. 9:OT006.

Brand, T. 2006. In vitro activity of fungicidal compounds towards conidial germination and mycelial growth of Cylindrocladium buxicola. Nachrichtenbl. Deut. Pflanzenschutz. 58:117-121.

Dart, N., Hong, C. X., Craig, C. A., Fry, J. T., and Hu, X. R. 2015a. Soil inoculum production, survival, and infectivity of the boxwood blight pathogen, Calonectria pseudonaviculata. Plant Dis. 99:1689-1694.

Dart, N. L., Allen, C., and Hong, C. X. 2015b. Efficacy of bleach and ethanol as sanitizers on the boxwood blight pathogen, Calonectria pseudonaviculata. Virginia Nursery and Landscape Association Newsletter 85(January/February/ March Issue): 46-47.

Eskandari, F., and Shishkoff, N. 2017. Both boxwood blight pathogens (Calonectria pseudonaviculata and $C$. henricotiae) can infect boxwood roots. (Abstr.) Phytopathology 107:S4.3.

Ganci, M. L. 2014. Investigation of host resistance in Buxus species to the fungal plant pathogen Calonectria pseudonaviculata (=Cylindrocladium buxicola), the causal agent of boxwood blight and determination of overwinter pathogen survival. North Carolina State University, Raleigh, NC.
Gehesquière, B. 2014. Cylindrocladium buxicola (syn. Calonectria pseudonaviculata) on Buxus: Molecular Characterization, Epidemiology, Host Resistance and Fungicide Control. Ghent University, Belgium.

Henricot, B., Gorton, C., Denton, G., and Denton, J. 2008. Studies on the control of Cylindrocladium buxicola using fungicides and host resistance. Plant Dis. 92: 1273-1279.

Henricot, B., and Wedgwood, E. 2013. Evaluation of foliar fungicide sprays for the control of boxwood blight, caused by the fungus Cylindrocladium buxicola. Plant Health Prog. 14:1.

Ivors, K. L., Lacey, L. W., and Ganci, M. 2013. Evaluation of fungicides for the prevention of boxwood blight, 2012. Plant Dis. Manage. Rep. 7:OT014.

Kader, M. A., Senge, M., Mojid, M. A., and Ito, K. 2017. Recent advances in mulching materials and methods for modifying environment. Soil Tillage Res. 168:155-166.

Kong, P., and Hong, C. X. 2017. Biocontrol of boxwood blight by Trichoderma koningiopsis $\mathrm{Mb} 2$. Crop Prot. 98:124-127.

Kong, P., Likins, T. M., and Hong, C. X. 2017a. First report of blight of Sarcococca hookeriana var. humilis by Calonectria pseudonaviculata in Virginia. Plant Dis. 101:247.

Kong, P., Likins, T. M., and Hong, C. X. 2017b. First report of Pachysandra terminalis leaf spot caused by Calonectria pseudonaviculata in Virginia. Plant Dis. 101:509.

LaMondia, J. A. 2014. Fungicide efficacy against Calonectria pseudonaviculata, causal agent of boxwood blight. Plant Dis. 98:99-102.

LaMondia, J. A. 2015. Management of Calonectria pseudonaviculata in boxwood with fungicides and less susceptible host species and varieties. Plant Dis. 99: 363-369.

LaMondia, J. A. 2017. Pachysandra species and cultivar susceptibility to the boxwood blight pathogen, Calonectria pseudonaviculata. Plant Health Prog. 18:41-43.

LaMondia, J. A., and Shishkoff, N. 2017. Susceptibility of boxwood accessions from the National Boxwood Collection to boxwood blight and the potential for differences between Calonectria pseudonaviculata and $C$. henricotiae. HortScience 52:873-879.

Malapi-Wight, M., Salgado-Salazar, C., Demers, J. E., Clement, D. L., Rane, K K., and Crouch, J. A. 2016. Sarcococca blight: Use of whole-genome sequencing for fungal plant disease diagnosis. Plant Dis. 100:1093-1100.

Moyer, T. 2016. Boxwood blight infects Woodrow Wilson gardens. Virginia Nursery Landscape Association Newsl. 86(April/May/June): 46.

Shishkoff, N. 2016. Survival of microsclerotia of Calonectria pseudonaviculata and C. henricotiae exposed to sanitizers. Plant Health Prog. 17:13-17.

Shishkoff, N., Daughtrey, M. L., Aker, S., and Olson, R. T. 2015. Evaluating boxwood susceptibility to Calonectria pseudonaviculata using cuttings from the national boxwood collection. Plant Health Prog. 16:11-15.

Stirling, G. R., and Eden, L. M. 2008. The impact of organic amendments, mulching and tillage on plant nutrition, Pythium root rot, root-knot nematode and other pests and diseases of capsicum in a subtropical environment, and implications for the development of more sustainable vegetable farming systems. Australas. Plant Pathol. 37:123-131.

USDA-NASS 2014. 2012 Census of Agriculture, 2014 CHS - United States Data

Van Laere, K., Hermans, D., Leus, L., and Van Huylenbroeck, J. 2015. Interspecific hybridization within Buxus spp. Sci. Hortic. (Amsterdam) 185:139-144.

Yang, X., and Hong, C. X. 2017. Evaluation of biofungicides for control of boxwood blight on boxwood, 2017. Plant Disease Manage. Rep. 11:OT023.

Yang, X., and Hong, C. X. 2018. Biological control of boxwood blight by Pseudomonas protegens recovered from recycling irrigation systems. Biol Control 124:68-73. 